\title{
EVIDENCES OF SCIENTIFIC MIRACLE OF AL-QUR'AN IN THE MODERN ERA
}

\author{
Dwi Sukmanila Sayska' dan Jani Arni² \\ ${ }^{1}$ STAIN Gajah Putih Aceh \\ ${ }^{2}$ UIN Sultan Syarif Kasim Riau \\ dwi.sayska@gmail.com
}

\begin{abstract}
One of the miracles of al-Qur'an is i'jaz ilmi, it's meant the information of al-Qur'an about science which is then able revealed and proven in accordance with the development of science. I'jaz ilmi does not present itself, but should be explored and researched, so that the evidence of i'jaz ilmi can be more and more and grow over time. Scientists gave the parable is like a spring that never runs dry. Every time always comes new discoveries and scientific provisions which already hinted at al-Qur'an for 14 centuries ago as evidence of i'jaz. I'jaz ilmi later became a effective propaganda media, especially among scientists. Many cases found confession of scientists when they were able to prove the truth of which is informed by al-Qur'an. In addition, evidence of ilmi i'jaz is able to ward off external oblique view of Islam that al-Qur'an is man work, because when they know that what is described by alQur'an has been proved by modern scientific discoveries, and eventually they acknowledges that al-Qur'an is really the word of God.
\end{abstract}

Keywords: Miracle, Scientific, and al-Qur'an

\begin{abstract}
Abstrak
Salah satu kei'jazan al-Qur'an adalah i'jaz ilmi, maksudnya informasi al-Qur'an tentang ilmu pengetahuan yang kemudian mampu diungkap sesuai dengan perkembangan ilmu pengetahuan tersebut. I'jaz ilmi ini tidak muncul dengan sendirinya, namun harus ditelusuri dan diteliti, sehingga dari waktu ke waktu i'jaz ilmi bisa semakin banyak dan bertambah. Para ilmuwan memberikan perumpamaan ibarat mata air yang tidak pernah kering. Setiap waktu selalu muncul penemuan baru dan ketetapan ilmiah yang sebenarnya telah diisyaratkan oleh al-Qur'an sejak 14 abad yang lalu. I'jaz ilmi ini menjadi media dakwah yang sangat efektif, terutama di kalangan ilmuwan. Banyak kasus dijumpai bersyahadatnya para ilmuwan ketika mampu membuktikan kebenaran yang diinformasikan al-Qur'an. Di samping itu, juga terdapat pandangan miring dari luar Islam bahwa al-Qur'an itu adalah hasil karya manusia, tetapi ketika mereka mengetahui bahwa apa yang diterangkan al-Qur'an telah dibuktikan oleh penemuan ilmiah modern, maka pada saat itulah mereka mengakui bahwa al-Qur'an benar-benar firman Allah.
\end{abstract}

Kata kunci: Mukjizat, Ilmiah, dan al-Qur'an 


\section{Introduction}

Al-Qur' an al-Karim is a book that serves as guidance for mankind. Al-Qur' an al-Karim is i' $\mathrm{jaz}$ or in the sense that this book can weaken the man to bring arguments such al-Qur'an. Both hidayah and i'jaz - are the reason why al-Qur'an was revealed, as well as with both methods that he spoke, and based on these two factors he postulates. Among the objects of scientific miracle study of al-Qur' an is kauniyah verses or passages that mention about natural phenomena. Al-Qur'an is giving enough hints about its association with science information. The scholars of interpretation also do not live in information link between alQur'an and science. In the field of exegesis is known as Tafsir ilmi. ${ }^{1}$ It can be defined by explaining the meaning of al-Qur'an involving science information, both natural science and social science. Tafsir ilmi is so developed in modern science era as today. The style of this interpretation is still growing despite the cleric questioned about his whereabouts.

Scientific miracles later become one of Uslub in dakwah to Allah, in which Allah opened so many secrets of nature and creation, which makes humans so fascinated with all the sciences of nature and its results. ${ }^{2}$ An example is Maurice Bucaille a surgeon and an autopsy from French who did research on the mummy of Pharaoh. From the research results proved that the mummy of Pharaoh contain the remains of salt water in which the Pharaoh was drowned, so Bucaille express the truth contained in al-Qur'an:

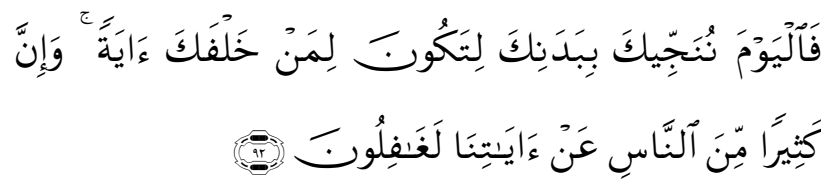

Today We shall cause to swim your dead body,

\footnotetext{
${ }^{1}$ Abdul Majid al-Zindany, Mukjizat al-Qur'an dan alSunnah mengenai IPTEK (Jakarta: Gema Insani Press, 1999), 26.

${ }^{2}$ Zaghlul al-Najjar, Min al-Ayat al-I'jaz al-Ilmy: al Sama “ (Beirut: Dar al-Ma'rifah, 2001), 30.
}

so that you might be a sign to those after you. And no doubt,people are heedless of Our signs (QS. Yunus: 92).

But an important thing to note is that God does not degrade al-Qur'an to be the one book that explains to people about scientific theories, problems of art and miscellaneous knowledge. ${ }^{3}$ However, al-Qur'an is a book that contains instructions about monotheism, direction, alignment belief, behavior, and so forth.

Indeed, many scholars have argued that i'jaz a-Qur'an form the most prominent in the 20th century is $i$ 'jaz ilmi. This is because many verses containing scientific nature that are overlooked or not realized by the previous group, and no clear meaning, but after doing scientific research. So here, it had begun efforts to dig al-Qur' an verses with Tafsir Ilmi approach. But, in the opinion of Yusuf al-Qaradhawy, ${ }^{4}$ the nature of $i^{\prime}$ 'jaz ilmi in al-Qur'an is actually just the miracle rhetorically, where there is not the slightest contradiction between al-Qur'an which has dropped 14 of the last century and various discoveries of contemporary science, and even some have also alluded al-Qur'an globally. If only al-Qur'an is a book authored by humans with their mind, his expressions surely will not be able to cover all the different ages and is not able to follow the development of human beings. Therefore, fundamental in setting i'jaz ilmi should be on issues that are clear and standard, which does not invite doubt and skepticism.

What interesting to study in al-Qur'an information is about science or scientific cues capable revealed by modern scientists. Therefore, this paper will examine any scientific miracles contained in al-Qur'an that has been proven through experiments in modern era, as well as

\footnotetext{
${ }^{3}$ Mahmud Syaltut, Tafsir al-Qur'an li Ajza' al- 'Asharatu al-Ula (Kairo: Dar al-Qalam, t.th), 21.

${ }^{4}$ Yusuf al-Qaradhawy, Kaifa Nata'amal ma'a al-Quran (Kairo: Dar al-Syuruq, 1999), 455.
} 
the efforts undertaken in the contemporary era to uncover Scientifics of al-Qur'an.

\section{Scientific interpretation of al-Qur'an}

Scientific interpretation of al-Qur'an is known as Tafsir ilmi. What is meant by Tafsir ilmi is interpretation in which included modern sciences, both on the nature and his theories, to explain the purpose and meanings of al-Qur'an. ${ }^{5}$ Yusuf al-Qaradhawy further explains that the modern sciences in question is physics, geology, chemistry, biology, involving plants and animals, medical sciences, anatomy, bodily functions, mathematical sciences, and others. While Said Agil al-Munawwar as quoted by Ali Akbar in his article scientific interpretation is the interpretation of kauniyah verses contained in al-Qur'an by associating them with modern sciences that arise in the present. ${ }^{6}$ Two definitions above show the broader scope of science proposed by Yusuf alQaradhawy than Said Agil al-Munawwar.

The terms put forward by Yusuf alQaradhawy in using this tafsir ilmi is: First: Stick to the facts instead of the hypothesis, or the sciences that have been established by the expert through research and testing beforehand. Second: do not impose in understanding the texts. Third: do not accuse all stupid people. ${ }^{7}$

Sheikh Abd al-'Azim al-Zarqani proposed certain conditions in interpretation of al-Qur'an with scientific methods, they are: Let not go too far in interpreting the intent to not run away from the origin of al-Qur'an as guidance and i'jaz. This interpretation also should resemble Tafsir not a science book. These studies let encourage the revival of the Muslims and make them aware of the majesty of Qur' an and not in a hurry to make a decision that is believed about kauniyah verses mentioned in al-Qur'an, but if it has a proposition

${ }^{5}$ Ibid., 421.

${ }^{6}$ Ali Akbar, "Kontribusi Teori Ilmiah terhadap Penafsiran", dalam Jurnal Ushuluddin 23, no. 1 (2015): 33.

${ }^{7}$ Yusuf al-Qaradhawy, 436-438. and solid arguments and has been proven. Now if there is any doubt then should we silence ourselves, and presents it to God is Aware and Wise. $^{8}$

\section{Scientific Miracles in al-Qur'an}

The examples of scientific miracles in alQur'an are:

1. The process of man creation on the stage of Fetal growth in embryology science. Allah SWT says:

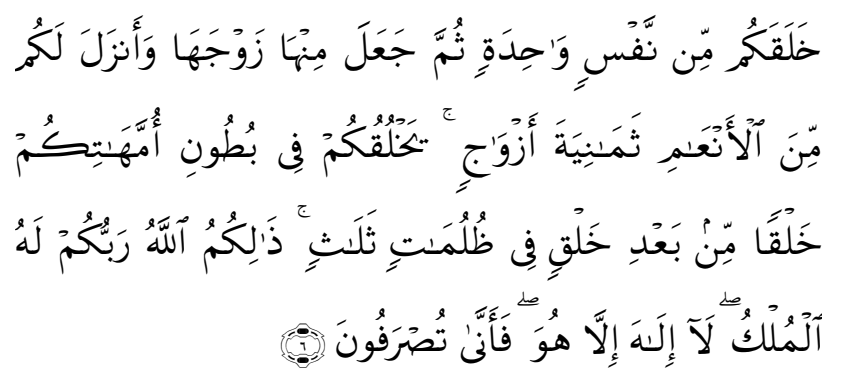

He has made you of a single soul then He made its mate from that and sent down for you eight pairs of cattle. He makes you in the wombs of your mothers, first in one pattern then in another, in three fold darkness. This is Allah your Lord, His is the kingdom. None is to be worshipped, besides Him, then where are you turning away? (az-Zumar: 6).

In another Surah, Allah Says:

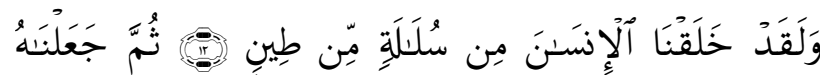
نُطْفَةً فِى قَرَارِ مَّكِينِ

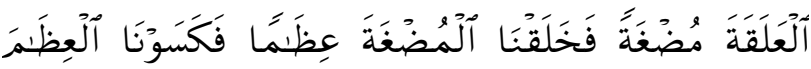

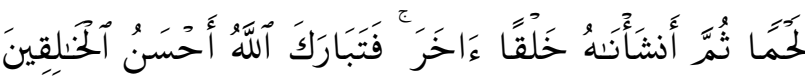

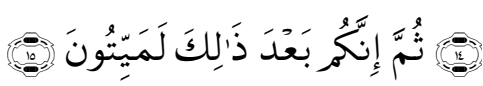

${ }^{8}$ Muhammad Abdul 'Azhim al-Zarqany, Manahil al-Irfan Fiy Ulum al-Quran, Jilid 2 (Kairo: Dar al-Hadis, 2001), 101-104. 
And certainly did We create man from an extract of clay (12). Then We placed him as a sperm-drop in a firm lodging (13). Then We made the sperm-drop into a clinging clot, and We made the clot into a lump [offlesh], and We made [from] the lump, bones, and We covered the bones with flesh; then We developed him into another creation. So blessed is Allah, the best of creators (14). Then indeed, after that you are to die (15) (QS. al-Mukminun: 12-15).

Allah explanation about the creation of man in above verses is supported by the scientific discoveries of the modern age. According to the embryology science newly revealed in this $20^{\text {th }}$ century, the process of human events is divided into three periods during the 9-month fetus in the mother's womb, as the medical term called trimester 1, 2 and 3. In terms of embryology, after meeting the sperm/male gamete with female gametes can produce a zygote (full cell) which will turn into an embryo and transferred to the uterus/womb and develop and grow into a fetus. This is the first darkness as mentioned in alQur'an, or the first trimester in medical terms (the first phase of 3 months). On a second darkness or second trimester, the fetus is enlarged again and has had a face, ears, mouth, nose and member of feet and hands. In the darkness of the third (third trimester) of the fetus entered in the $7^{\text {th }}$ until the $9^{\text {th }}$ month and was born a perfect baby. ${ }^{9}$

But in explaining the man creation from al'Alaq in Surah al-'Alaq, M. Quraish Shihab proposed corrections to the interpretation of the word al-Alaq with the meaning of a piece of flesh/ blood. He explained that in discussing al-'Alaqwhich by the previous mufassirin interpreted to freeze blood - was found contradiction between the interpretation and the results of scientific

\footnotetext{
${ }^{9} \mathrm{Abu}$ Hasan bin H. Ali, Ensiklopedi Pendidikan Sains dalam al-Quran, Jilid 5 (Kuala Lumpur: Emedia Publication, 2005), 30.
}

investigation. Because the ovum period consists of ectoderm, endoderm and amniotic cavity, the amniotic fluid contained therein. These elements do not contain the slightest blood components. From this starting point of contemporary interpreters reject the interpretation of al-'Alaq with a blood clot, either liquid or frozen. They argue that al-'Alaq is something dependent or huddle. This interpretation is consistent with the understanding of the Arabic language, and also in accordance with embryology science, called implantation. ${ }^{10}$ Arabic does not make sense of al'Alaq specifically for frozen blood, but one of the means is dependent or huddle. Al-Raghib alAshfahaniy in al-Mishbah al-Munir dictionary interpret al-'Alaq as "something black as worms in the water, when drunk by animals or obstructed it will depend on the throat". ${ }^{11}$

2. The process of the heavens and the earth creation in astronomy science.

Allah SWT says:

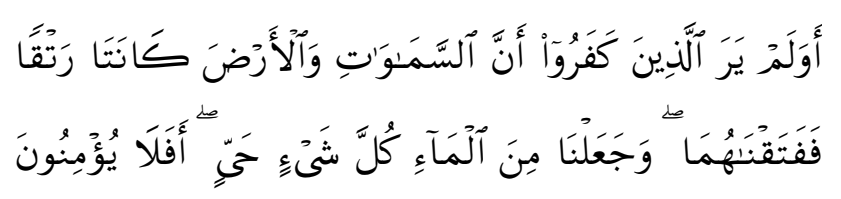

Have not those who disbelieve known that the heavens and the earth were joined together as one united piece, then We parted them? And We have made from water every living thing. Will they not then believe? (al-Anbiya': 30 ).

Proven this verse is true, strengthened by Big Bang Theory shows that all things in the universe at the beginning is one then were parted. This means that the whole matter is created by a gigantic explosion of a single point approximately

\footnotetext{
${ }^{10}$ M. Quraish Shihab, Tafsir al-Misbah (Jakarta: Lentera Hati, 2004), 120.

${ }^{11}$ Nadim Mar'asyli (Ed), Mu'jam Mufradat li Alfazhi alQuran (t.tp: t.p, t.th), 355.
} 
15 billion years ago, and now makes up the universe by means of separation from each other. In 1948, Gerge Gamov said that after the formation of universe through a giant explosion, residual radiation left by this explosion must necessarily spread evenly in all corners of the universe. In 1965, two researchers named Arno Penziaz and Robert Wilson discovered these waves by accident, called 'cosmic background radiation'. Thus, it is known that this radiation is radiation leftover relic from the early stages of the Big Bang because it did not seem to radiate from a particular source, but covers the entire space. In 1989, NASA sent the Cosmic Background Explorer satellite. COBE was into space to do research and only need 8 minutes for COBE to find evidence of residual giant explosions that had been occurred in the early formation of the universe that proves the theory of the Big Bang. ${ }^{12}$

In line with the cue indicated by al-Qur'an in verse above, to this day, the universe in which we live it increasingly expands and extends up to the day that God set when doomsday arrives. In 1929, at the California Mount Wilson observatory, Edwin Hubble observed and found that stars emit red light according to the distance. According to physics laws, the spectrum of the light source is moving closer to the observer tends to purple, while observers tend to stay away from red. This means that these stars are constantly moving away from us. The only thing that can be concluded is that the universe constantly "expands". Expansion of the universe also means that if the universe can move backward into the past, then it will prove to come rather than a single point. The calculations showed that this 'single point' that harbored all the matter of the universe should has 'zero volume' and 'infinite density' also means that come from 'nothing'. Thus the universe arose because it has been created by Allah, the Creator

\footnotetext{
${ }^{12}$ Zaghlul al-Najjar, 100-103; Harun Yahya, www.harunyahya.com.
}

of heaven and earth. ${ }^{13}$

3. The difference of sea water taste

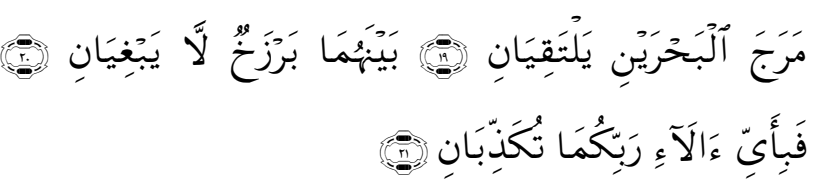

He made flow two seas that look to be joined (19). And there is Carriers in between them that one cannot excel the other (20). Which then, of the favours of your Lord will you twain deny? (21) (QS. ar-Rahman 19-21).

Among the interpreters have argued that the "La Yabghiyan" means each one does not want. Thus the intention of verses 19-20 is that the two separate seas are both limited by an isthmus but it is not desired (not necessary), then in the end isthmus was discharged (excavated for the purpose of traffic), then both meet in ocean. Such as Suez Canal and Panama Canal. ${ }^{14}$ It apparently been proven now that in the bottom of the Red Sea are the source of freshwater springs that flow continuously and does not mix with the surrounding water is salty. In this verse also gives the same information, the word of God: "And He it is Who hath given independence to the two seas (though they meet); one palatable, sweet, and the other saltish, bitter; and hath set a bar and a forbidding ban between them" (QS. al-Furqaan: 53). Two ocean do not mix are located in Gibraltar Strait, the strait that separates African continent and Europe, precisely between Morocco and Spain. ${ }^{15}$

Thus it is example of al-Qur'an interpretation through a scientific approach, in order to demonstrate the scientific miracles of the

\footnotetext{
${ }^{13}$ Zaghlul al-Najjar, 88-89; Harun Yahya, www.harunyahya.com

${ }^{14}$ Depag RI, al-Quran dan Terjemahannya (Toha Putra: Semarang, 2002), 774.

${ }^{15}$ https://rinaldimunir.wordpress.com/2011/12/09/ kebenaran-surat-ar-rahman-19-20-dua-laut-yang-tidakpernah-bercampur/
} 
al-Qur'an, Allah has revealed 14 centuries ago through the oral His Messenger glorious. AlQur'an also provide cues to the laws of nature and the phenomenon of life with a very convincing picture, which may not be contradictory to the findings of human achievement in the various phases and levels.

Therefore, Muslim scientists contemporary were so inspired to reveal the scholarly al-Qur'an by stating that the verses of science in al-Qur'an is a dakwah language nowadays, in which alQur'an was revealed to the Messenger that "ummy" and people who do not knows absolutely nothing about the nature of science and scientific knowledge has hinted scientific evidence that was revealed last few decades. This is what can be a way to preach to God by proving that al-Qur'an is essentially a divine revelation and showed signs of Allah in the heavens and on earth.

\section{Scientific Cues in al-Qur'an}

Scientific cues in al-Qur'an is so comprehensive and covers all fields of science, we can see in the list of kauniyah verses contained in the various books of tafsir ilmi and written by scholars about it. Tantawi Jauhary (w.1940 M/ $1358 \mathrm{H}$ ) in Tafsir Jawahir - which is the first book discusses scientific interpretation of alQur'an complete, consisting of 26 volumes covering 30 juz - mention that kauniyah verse in al-Qur'an more than 750 verses. ${ }^{16}$ Meanwhile, according to ilmi contemporary interpreters, as expressed by Zaghlul al-Najjar, Chairman of the Institute of Scientific al-Qur'an and al-Sunnah in the Supreme Council for Islamic Affairs of Egypt, that kauniyah verse in the al- Qur'an is more than a thousand verses. ${ }^{17}$

Among the disciplines covered in kauniyah verses in al-Qur'an are:

${ }^{16}$ Tantawi Jauhary, Tafsir al-Jawahir, Vol. 25 (Kairo: Muassasah Mustafa al-Babi al-Halabi, 1970), 55-56.

${ }^{17}$ Zaghlul al-Najjar, 17.
1. Astronomy ${ }^{18}$, Allah SWT say:

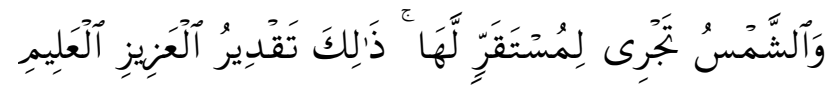

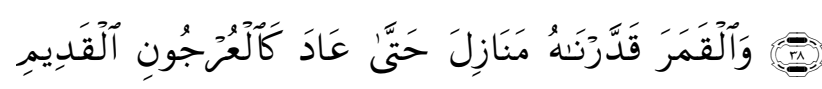

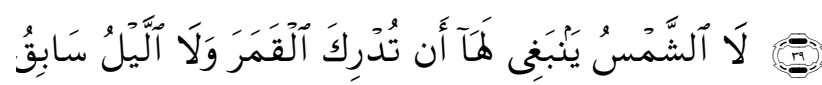

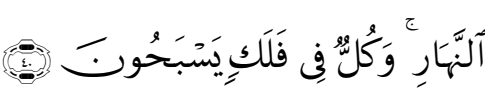

And the sun runneth on unto a resting-place for him. That is the measuring of the Mighty, the Wise (38). And for the moon We have appointed mansions till she return like an old shrivelled palm-leaf (39). It is not for the sun to overtake the moon, nor doth the night outstrip the day. They float each in an orbit (40) (QS. Yasin: 38-40).

Previously, scientists still argue that the sun does not move or stand still. However, this verse implies that the sun moves in the indicated direction. It was revealed by scientists in the early 20th century. Astronomers explained the sun was surrounded by a collection of celestial bodies which composed of planets, moons and comets always follow the sun and comply with the gravitational force of the sun. So this collection circulate around it on the trajectory (orbit) is oval. All part of this group move with the sun according to the sun movement. Set of celestial bodies that surround the sun moves through the sky in a certain speed and direction, speed of approximately $700 \mathrm{~km}$ per second. The circulation runs regularly around the center point of the sun measuring light travels 200 million years.

Verse 39 explains that the moon is not in one form only. However, the moon can appear with different shapes up to be a full moon. The moon has the same shape at the beginning and

\footnotetext{
${ }^{18}$ The calculation of the number of verses related to each discipline based on the M. Darwis Hude, et.al., Cakrawala Ilmu dalam al-Qur'an (Jakarta: Pustaka Firdaus, 2002), 18.
} 
end of its circulation. The first resembles a crescent, then the full moon, and afterwards was like a scythe back.

In verse 40 asserts that night and day are both outstanding. One another will not precede each other. This is a proof that the earth is round. It is also an indication that both night and day are in one time on the surface of the earth. Suppose the earth is flat, then there will be only one time. Day forever or night forever. ${ }^{19}$

Such an explanation can only be revealed by scientists of $20^{\text {th }}$ century. In the case of alQur'an had been informed since $14^{\text {th }}$ centuries ago. This is a proof that al-Qur'an is derived from Substance the Omniscient.

\section{Biology}

There are 67 verses speak about biological sciences, one of them:

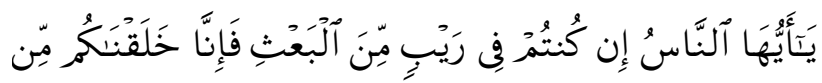

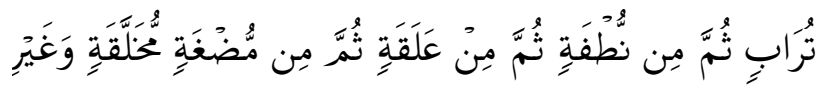

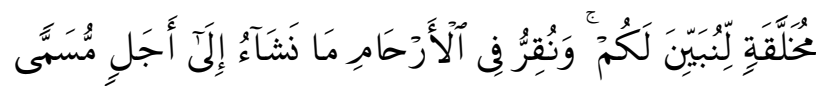

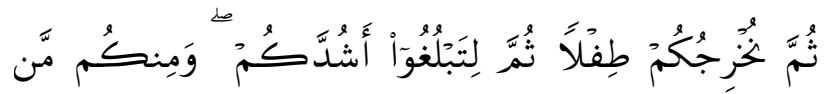

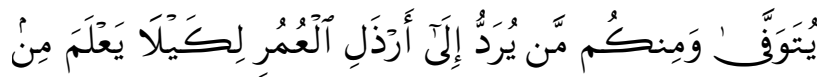

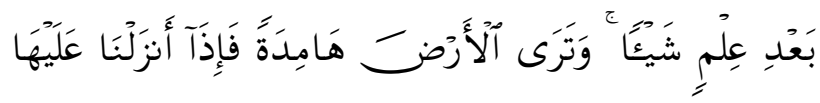

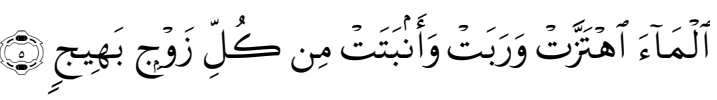

"O mankind! if ye are in doubt concerning the Resurrection, then lo! We have created you from dust, then from a drop of seed, then from a clot, then from a little lump of flesh shapely and shapeless, that We may make (it) clear for you. And We cause what We will to remain in the wombs for an appointed time, and afterward We bring you forth as infants, then

${ }^{19}$ Muhammad Kamil Abdushshamad, Mukjizat Ilmiah dalam al-Qur'an, Terjemahan (Jakarta: Akbar Media Eka Sarana, 2003), 29-31. (give you growth) that ye attain your full strength. And among you there is he who dieth (young), and among you there is he who is brought back to the most abject time of life, so that, after knowledge, he knoweth naught. And thou (Muhammad) seest the earth barren, but when We send down water thereon, it doth thrill and swell and put forth every lovely kind (of growth)" (QS. al-Hajj: 5).

In the biological sciences that water is the most important and vital to all living beings, whether human, plant or animal. Plants make ends meet for water to absorb water containing various minerals that are essential for the survival of soil. Once absorbed, then distributed to all parts of his body. Natural and organic fertilizer well absorbed and distributed in the same way. It was described by surah al-Hajj verse 5, on the phrase "wa tara al-ardha hamidatan"

Scientists from the University of Wales Australia conducted a series of research on plants that experience water shortages. They noted the weak signals coming out of the leaves and stems of the tree. By using highly sensitive equipment, they managed to capture the sound signals. Apparently, after comparing the signals plants enough water to drought signal plants, plants that are drought much stronger. It is as if the plants screaming and screaming for water. ${ }^{20}$

\section{Geography}

There are 43 verses that talk about geography science, one of them:

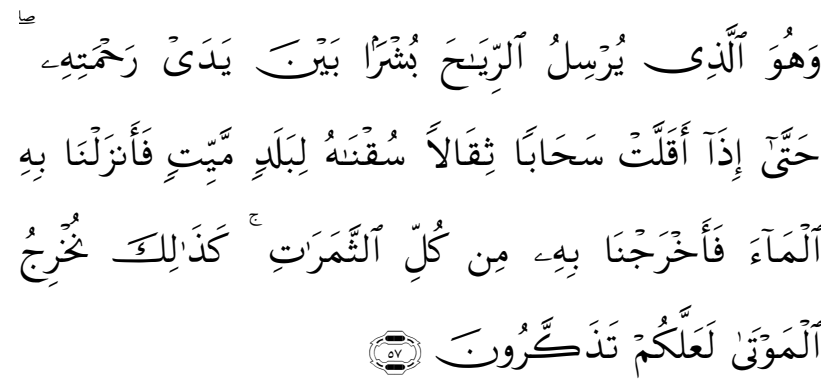

${ }^{20}$ Ibid., 183-184. 
"And He it is Who sendeth the winds as tidings heralding His mercy, till, when they bear a cloud heavy (with rain), We lead it to a dead land, and then cause water to descend thereon and thereby bring forth fruits of every kind. Thus bring We forth the dead. Haply ye may remember" (QS. al-A'raf: 57).

In recent, geography explains that there are relationship between clouds, rain, and wind. While the above verses have been first made it clear that the wind carried a cloud, which then will be rain. Scientists explain that the presence of clouds and rain affected by the movement of wind. The movement of the wind currents will form clouds piles. Clouds piles of the air currents would perfectly upright. The first will lead to a drizzle, which further become heavy rains. The harmony between the clouds and the wind direction is able to fall. If man made artificial rain, it is highly dependent on the direction of the wind, when the wind direction is not perfect, then this artificial rain was not going to work. ${ }^{21}$

\section{Geology}

Geology is a branch of science deals with the earth, its composition, structure, physical properties, history, and the process of formation. There are 13 verses that talk about this science branch, one of them:

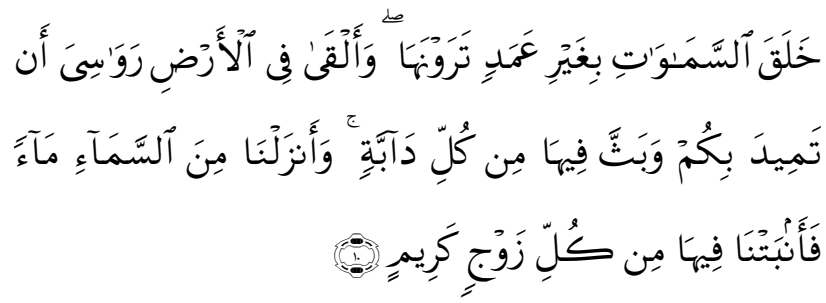

"He hath created the heavens without supports that ye can see, and hath cast into the earth firm hills, so that it quake not with you; and He hath dispersed therein all kinds of beasts. And We send down water from the

\footnotetext{
${ }^{21}$ Ibid., 106-108.
}

sky and We cause (plants) of every goodly kind to grow therein" (QS. Luqman: 10).

The above verse informs that Allah SWT created the heavens and the earth. God created the heavens without any pillars, but do not fall on the earth. While on earth there are mountains serves to keep a balance, so that the earth does not shake. Through the sky is nor a collision between planets, as the effect of the balance of the earth. This is valuable information in geology or the study of earth layers.

\section{Hydrology}

Hydrology is a branch of science study the distribution of water on earth, especially in the mainland. There are 27 verses talk about this branch of science, one of them:

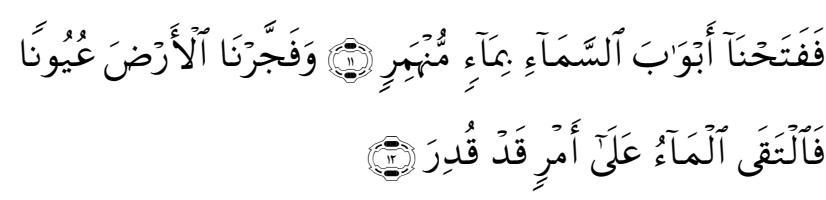

"Then opened We the gates of heaven with pouring water (11). And caused the earth to gush forth springs, so that the waters met for a predestined purpose (12)" (QS. al-Qamar: 11-12).

One cycle in hydrology science is the rain. The verse above talks about rain down to the earth. In addition, there are springs on the earth as a source of water, but when the water is not able to be absorbed by the earth; it is capable of causing a flooding disaster. Therefore need to preserve nature so that nature can save water.

\section{Medicine}

There are 16 verses that talk about this science branch, one of them:

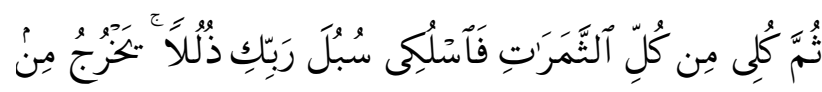

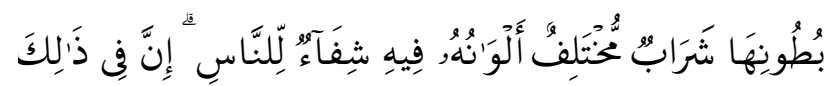

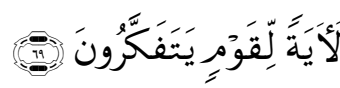


"Then eat of all fruits, and follow the ways of thy Lord, made smooth (for thee). There cometh forth from their bellies a drink divers of hues, wherein is healing for mankind. Lo! herein is indeed a portent for people who reflect" (QS. an-Nahl: 69).

Verse above clearly explains that different types of herbs and honey can serve as a remedy or antidote for humans. Modern medical science has proven that many of drugs, one of the compositions is herbs and honey.

\section{Chemistry}

There are 21 verses that talk about this, one of them:

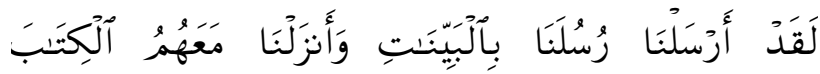

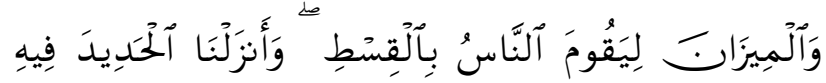

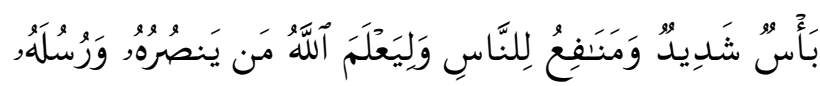

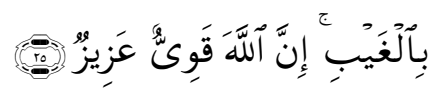

"Indeed We have sent Our Messengers with clear proofs, and revealed with them the Scripture and the Balance (justice) that mankind may keep up justice. And We brought forth iron wherein is mighty power (in matters of war), as well as many benefits for mankind, that Allah may test who it is that will help Him (His religion), and His Messengers in the unseen. Verily, Allah is All-Strong, AllMighty" (QS. al-Hadid: 25).

Based on the content of QS. al-Hadid: 25 above, Muslim scientists have examined the content contained therein which states that Allah SWT created and lowering the iron element which can be exploited by humans.

\section{Mineralogy}

Mineralogy is the earth science that focuses on the nature of chemistry, crystal structure, and physical (including optical) of the mineral. This study also includes the formation and alteration minerals. There are 14 verses that talk about this, onr of them:

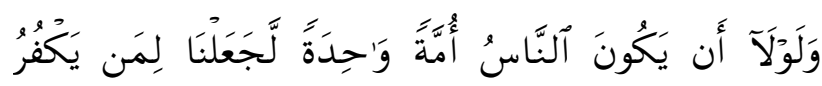

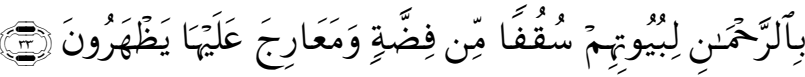

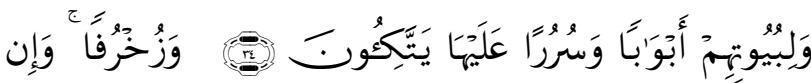

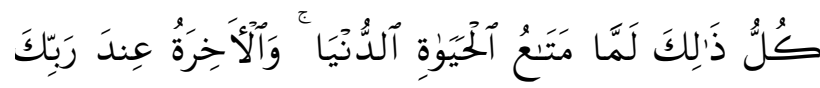
الِّمُتَّقينَ "And had it not been that all mankind would become of the same faith, We would have surely made for those who disbelieve in the All Affectionate, roofs of silver for their houses and stairs whereon they ascend (33). And for their houses silver doors and silvers couches upon which they recline (34). And various types of adornments. And all this is, it is only a provision of the life of this world. And the Hereafter with your Lord is for the Godfearing (QS. az-Zukhruf 33-35).

\section{Agriculture}

There are 46 verses that talk about this, one of them:
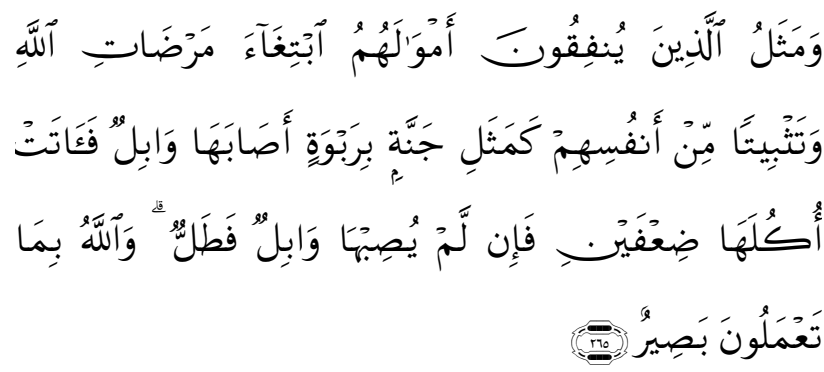

"And the example of those who spend their wealth in seeking the pleasure of Allah and for strengthening their hearts is like that garden which is on an elevated ground; a heavy rain fell upon it then it brought forth its fruits two fold; again if a heavy rain reaches it not, then dew suffices. And Allah is seeing what you do" (QS. al-Baqarah: 265). 
Verse above informs about the gardens are located in the highlands able to produce fruit bountifully. In line with the theory of farming that land is higher than the surface of the water, the leaves of the trees will be more widely grown, its roots deeper and longer, and more than doubled as well the number of capillaries that suck into the ground, so the more minerals are exploited to enrich the stem and leaves. This plants will bear fruit more quickly, and doubled as a blessing from God.

Instead, the garden planted parallel to the ground water, so it does not get sufficient air circulation in agricultural land. This resulted in many dead roots thus weakening the trees and is not able to spread freely in the soil. As a result, it certainly will not produce fruit that doubled as plants which live in the highlands. Therefore, if you'd like gardening then must consider the height of the land.22

\section{The technology}

There are 15 verses that talk about this, one of them:

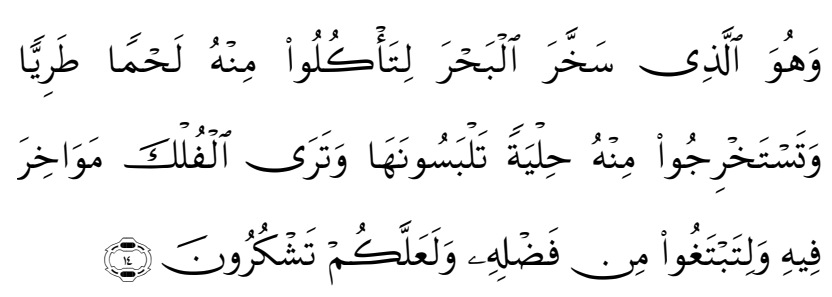

"And it is He Who has made the sea subservient for you. That you eat fresh flesh from it and bring forth from it ornaments which you wear. And you see boats cleaving through it. And that you seek of His bounty and that haply you may be grateful to Him” (QS. an-Nahl: 14).

Al-Biqa'i as quoted by M. Quraish Shihab in his book commentary, verse above explains that Allah SWT has subjected the oceans and rivers, and makes a life for animals and breeding and

\footnotetext{
${ }^{22}$ Ibid., 136-137.
}

the formation of various jewelries. It is made in order people can use it as him alive to serve as side dishes, or make it as jewelry such as gems, pearls, beads and others. ${ }^{23}$ With current technology, various results of oceans and rivers can be processed into various types of food or jewelry.

There are still many other branches of science that can be grouped in understanding of this kauniyah verse. This is a proof that al-Qur'an is a book that is full of miracles is always in line with the development of human and future travels until doomsday later. Therefore, the efforts of the al-Qur'an interpretation with explanation of science, increasingly, conducted by scholars and experts of Muslim science. In September 1975 held a first conference to discuss the medical miracles in al-Qur'an. The event was attended by Sheikh Azhar: Mutawalli Sha'rawi, rector of alAzhar and the dean of faculty Perubatan, and the well-known doctors from various universities. This event also invited the present delegation from the Islamic Conference Organization and Medicine Organization delegations from various countries of Islamic Organization. From nonMuslims were invited expert Genealogy, Prof. Keith More ${ }^{24}$ and Prof. Maurice Buccaille. ${ }^{25}$ The

\footnotetext{
${ }^{23}$ M. Quraish Shihab, 200.

${ }^{24}$ Dr. Keith L. Moore, a professor of Anatomy and the University of Toronto ever awarded J.C.B. Grant Award in 1984, and wrote approximately 150 articles in the fields of anatomy and embryology, in addition to several books including The Developing Human: clinically Oriented Embryology, tasteless amazed by the verses of al-Qur'an that tell regarding the science of embryology. In the introduction to his book The Developing Human: clinically Oriented Embryology third edition, he said: "For three years I cooperated with the championship Embryology at the University Abdul Aziz, to help them interpret the verses of al-Qur'an and hadith relating to human events and embryos in the womb. I am really amazed by the accuracy of the verses of al-Qur'an that was revealed in the seventh century compared with the discoveries during, whereas when the science of embryology is still in existence. During this time I never knew the contents contained in al-Qur'an and Sunnah"(Http / www.bicara-muslim.com).

${ }^{25}$ Dr. Maurice Bucaille, a prominent science of France. In the book the titled La Bible, le Coran et la Science, he
} 
conference was a success and amazing. There was a revealed flank scientific miracle or i'jaz ilmi of al-Qur'an which is corroborated by the doctors from Canada, America, Britain, and France. One of the doctors who attended even directly pledged creed. It can be said that it is the impact of the direction of truth and the methods they use in interpreting al-Qur'an through a scientific approach. ${ }^{26}$

Until now, it has been many international conferences conducted in reviewing and discussing about $i$ 'jaz ilmi in al-Qur'an to interpret kauniyah verses through science approach and scientific discovery. It also had a positive impact in the development of science and technology and the advancement of science in the Muslim community. Among other things, we certainly know the name of Harun Yahya is a lot of uncovering the truth of al-Qur'an through a variety of scientific research. In fact, It is now presented not only in book form, but also in the form of a documentary film or video impressions are translated into the various languages of the world. In addition, between institutions nationally and internationally are too spicy in the scientific interpretation of al-Qur'an aim to spread dakwah about the scientific miracles of al-Qur'an, it is able to trigger a scientific revival of Muslims and disseminate to non-Muslims the messages and guidance al-Qur'an. Among these institutions are:

1. Institutions of i'jaz ilmi in al-Qur'an and alSunnah at Rabithah Alam Islamy in Makkah al-Mukarramah,

2. The Supreme Council for Islamic Affairs in Egypt,

3. Organization of Ilmi I'jaz in al-Qur'an and al-Sunnah in Egypt,

4. Islamic Foundation for Medicine in Kuwait,

5. Academy of Islamic sciences in Oman,

6. Institutions of i'jaz Ilmi al-Qur'an and al-

${ }^{26} \mathrm{Jamal}$ al-Banna, Tafsir al-Quran al-Karim Baina alQudama wa al-Muhaditsin (Kairo: Dar al-Fikr al-Islamy, 2003), 191.
Sunnah in Bangladesh,

7. Discussion i'jaz Ilmi Centre in Bangladesh. ${ }^{27}$

The possibility of many more national and international institutions are working hard in the discussion of scientific studies of al-Qur'an, and all of which contribute greatly to the propagation of Islam. Through the disclosure of the secrets of nature by kauniyah verses will further strengthen the faith in the hearts of believers to the truth of al-Qur'an, sensitize hypocrite, bracing converts, against the mutineers, and even become a way of guidance for those who have not embraced this Hanif religion. Also evoke a positive image of Islam, the only religion that never contradicts with the findings of science and modern science is evidence that al-Qur'an was revealed by Allah Ta'ala, the Creator and Ruler of the universe through His oral prophet glorious more reliable, Rasulullah shalallahu 'alaihi wasallam.

\section{Conclusion}

Information of al-Qur'an about science and be able to be proven by modern invention, it is known by the scientific miracles of al-Qur'an. The ability of scientists to prove what is told al-Qur'an has become a dakwah media for scientists. Among the information of al-Qur'an that its science is capable evidenced by contemporary scientists are on the fetus in the womb of a mother (QS. alMukminun), the process of creation of the heavens and the earth (QS. al-Anbiya: 30), and the difference taste of sea water (QS. Yassin: 1921). Al-Qur'an also includes several disciplines, such as astronomy, geography, biology, botany, hydrology, and others. These cues have also been able to scientifically reveal by modern scholars. In addition, efforts to find information of alQur'an about science or scientific cues had been never stopped, and continues even today.

${ }^{27}$ Zaghlul al-Najjar, www.nooran.org. 


\section{Bibliography}

Abu Hasan bin H. Ali. Ensiklopedi Pendidikan Sains Dalam al-Qur'an. Kuala Lumpur: Emedia Publication, 2005.

Ali Akbar. "Kontribusi Teori Ilmiah terhadap Penafsiran". Dalam Jurnal Ushuluddin 23, no. 1 (2015).

al-Banna, Jamal. Tafsir al-Qur'an al-Karim Baina al-Qudama wa al-Muhaditsin. Kairo: Dar al-Fikr al-Islamy, 2003.

al-Dzahabi, Muhammad Husain. Al-Tafsir wa alMufassirun. Kairo: Maktabah Wahbah, 1995.

Jauhari, Tantawi. Tafsir al-Jawahir. Kairo: Muassasah Mustafa al-Babi al-Halabi, 1970.

M. Darwis Hude, et.al. Cakrawala Ilmu dalam al-Qur'an. Jakarta: Pustaka Firdaus, 2002.

M. Quraish Shihab. Membumikan al-Qur'an. Bandung: Mizan, 2002.
_. Tafsir al-Misbah. Jakarta: Lentera Hati, 2004.

Mar'asyli, Nadim (Ed). Mu'jam Mufradat li Alfazhi al-Qur'an. T.tp: t.p, t.th.

Muhammad Kamil Abdushshamad. Mukjizat Ilmiah dalam al-Qur'an. Jakarta: Akbar Media Eka Sarana, 2003.

al-Najjar, Zaghlul. Min al-Ayat al-I'jaz alIlmy: al Sama'. Beirut: Dar al-Ma'rifah, 2001.

al-Qaradhawy, Yusuf. Kaifa Nata'amal ma'a alQur'an. Kairo: Dar al-Syuruq, 2000.

Syaltut, Mahmud. Tafsir al-Qur'an li Ajza' al'Asharatu al-Ula. Kairo: Dar al-Qalam, t.th.

al-Zarqany, Muhammad Abdul 'Azhim. Manahil al-Irfan Fiy Ulum al-Qur'an. Kairo: Dar al-Hadis, 2001.

al-Zindani, Abdul Majid. Mukjizat al-Qur'an dan al-Sunnah mengenai IPTEK. Jakarta: Gema Insani Press, 1999. 